\title{
The Merging of Reciprocal Teaching and 5e Instructional Model: A Conceptual Framework
}

\section{Ting Pick Dew, Suyansah Swanto, \& Vincent Pang}

To Link this Article: http://dx.doi.org/10.6007/IJARBSS/v11-i3/8469

DOI:10.6007/IJARBSS/v11-i3/8469

Received: 07 January 2021, Revised: 10 February 2021, Accepted: 23 February 2021

Published Online: 21 March 2021

In-Text Citation: (Dew et al., 2021)

To Cite this Article: Dew, T. P., Swanto, S., \& Pang, V. (2021). The Merging of Reciprocal Teaching and 5e Instructional Model: A Conceptual Framework. International Journal of Academic Research in Business and Social Sciences, 11(3), 983-996.

Copyright: (c) 2021 The Author(s)

Published by Human Resource Management Academic Research Society (www.hrmars.com)

This article is published under the Creative Commons Attribution (CC BY 4.0) license. Anyone may reproduce, distribute, translate and create derivative works of this article (for both commercial and non-commercial purposes), subject to full attribution to the original publication and authors. The full terms of this license may be seen

at: http://creativecommons.org/licences/by/4.0/legalcode

Vol. 11, No. 3, 2021, Pg. 983 - 996

Full Terms \& Conditions of access and use can be found at http://hrmars.com/index.php/pages/detail/publication-ethics 


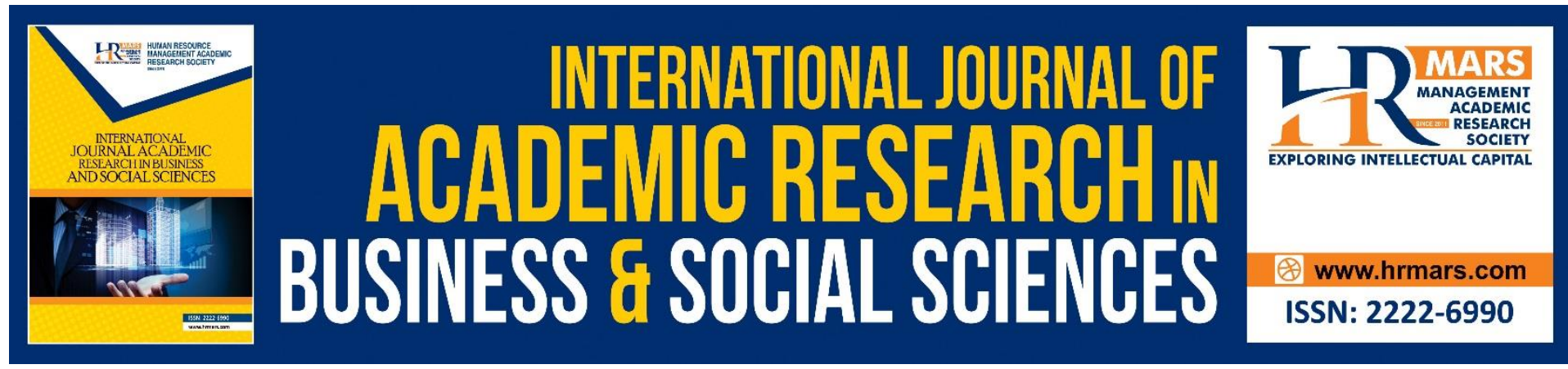

\title{
The Merging of Reciprocal Teaching and $5 e$ Instructional Model: A Conceptual Framework
}

\author{
Ting Pick Dew, Suyansah Swanto, \& Vincent Pang
}

Faculty of Psychology and Education, Universiti Malaysia Sabah

Email: elainepdting@gmail.com, suyansah@ums.edu.my, \& pvincent@ums.edu.my

\begin{abstract}
Reading entails cognitive and linguistics competencies, from basic decoding to complex comprehension structure that includes integration of one's knowledge of the world, thus is the main building blocks of learning and knowledge. However, reading is more than just the ability to recognize words and decode information. Successful reading requires an active interaction between the reader's interpretation of the printed information, critical evaluation of the message and application of the newfound knowledge. This requirement necessitates the need to activate reading comprehension strategies that facilitate the representational construction of a text. This conceptual paper highlights a framework that allows the scaffolding and meaning construction to be performed through modelling, guiding and application of reading strategies. The integration of reciprocal teaching which is an instructional technique that builds on modelling and scaffolding four reading strategies, into the five phases of the inquiry-based learning cycle might impel reluctant readers to regain interest in reading by learning the suggested strategies in the predetermined phases.
\end{abstract}

Keywords: Comprehension, Reading Strategies, Inquiry-Based Learning, Reciprocal Teaching, ESL Learners.

\section{Introduction}

Reading comprehension is highly complex, dynamic, multi-dimensional process that involves an orchestration of the reader's linguistic and background knowledge, appropriate application of cognitive and metacognitive reading strategies and correct decoding of the textual evidence (Elleman \& Oslund, 2019). Multiple interactions and coordination of various cognitive processing skills which include meaningful interpretation of the printed symbols, active interaction between the texts and the reader's world knowledge are essential elements in ensuring smooth and rapid comprehension progress. Successful reading requires readers to be able to manoeuvre their way through the complexity of reading (Grabe \& Stoller, 2020) and have good judgment on the selection of effective reading strategies (Lian \& Azlina, 2020) to accurately understand and interpret written materials.

However, this process does not occur automatically because it involves an amalgamation of reader's background knowledge, the textual evidence, reader's interpretation in relationship to the text (Grabe \& Stoller, 2020). Good readers utilise multiple reading strategies to resolve 
uncertainties and to reflect as well as to monitor their own comprehension (Ulu, 2019). A common presumption among educators is that ESL learners will grasp such relatively sophisticated skills and strategies after years of developing reading competency. Unfortunately, learners' ability to decode text in primary education does not always result in successful comprehension in secondary education (UNESCO, 2017). Similarly, Elleman and Oslund (2019) also postulate that the increasing complexity in the text might result in comprehension difficulties for skilled readers who gains clear understanding on simpler texts.

Globalization places heavy weight on reading as a fundamental skill for academic attainment and career development (Kim et al., 2019). A study by Mackay et al. (2019) revealed that poorer text generation performance is evident in university students with a history of reading difficulties. Inability to successfully comprehend the reading texts in primary grades will negatively impact the learners' reading ability throughout the learning process (Wanzek et al., 2018) as the lack of comprehension skills exacerbates the success of learning. As reading skills are essential elements in reading comprehension process (Karadag et al., 2019), application of appropriate reading strategies and awareness of reading purpose are equally crucial in escalating learners' reading comprehension and preparing them to be independent, efficient and critical readers.

A countermeasure to address this predicament of poor reading comprehension skills is by establishing a valid transaction of meaning between the reader and the text through the use of comprehension strategies instruction which includes both cognitive and metacognitive reading comprehension strategies (Elleman \& Oslund, 2019). Developing adequate reading comprehension strategies is pivotal as they improve readers' apprehension, rectify reading difficulties, and increase textual understanding (Oktovia \& Fitriana, 2017). Hence, in order to bridge the gap, ESL teachers need to have an awareness of the learners' needs, an understanding of the reading purposes, and strategies, as well as the ability to teach the necessary skills and approaches (Kim et al., 2019), thus necessitates slight modification on the way reading comprehension is taught in classrooms. This conceptual paper aims at proposing a conceptual framework that might help to better enhance ESL learners' reading comprehension by reviewing relevant literature on reading comprehension strategies and highlights the strategies that can be used to rectify the problems in reading comprehension.

\section{Literature Review}

The section reviews relevant literature on reading in Malaysian Education System, guided reading, inquiry-based learning, reciprocal teaching.

\section{Reading in Malaysian Education System}

In Malaysia, the heightened focus on English language and reading in the curriculum is evident in the alignment of the language curriculum framework with the Common European Framework of Reference for Languages (CEFR) that saw an implementation of the revised KSSM which led to the introduction of the Standard-Based English Language Curriculum for Secondary Schools (SBELC) with the main aims of reading focus on learners' ability to understand meaning and to extend thinking through independent reading (MOE, 2018). Teaching and learning activities in SBELC emphasize student-centred approaches such as inquiry-based learning, project-based learning, and cooperative learning that involve cognitive processes such as understanding, paraphrasing sentences and summarizing texts, 
and metacognitive processes which encompasses planning, regulating, monitoring and modifying the cognitive learning processes to acquire and understand information are highlighted. As these strategies accommodate difference in learning styles, teachers who act as facilitators are encouraged to use their professional judgment to review and then decide on the most appropriate strategies that meet their students' needs. Adoption of alternative approaches is allowed when needs arise. This empowerment allows for adjustments to suit learners' needs, thus optimises the learning process.

This heavy emphasis on reading in the curriculum is a result of low achievement in reading literacy rate in Malaysia. In 2009, Malaysia's ranking on PISA in Reading was 55 out of 74 countries with a mean score of 414 , which is below the OECD average score of 493 (OECD, 2010). In 2012, with the OECD average score at 496, Malaysia only managed to achieve a mean score of 398 and was placed at the rank of 59 out of 65 countries (OECD, 2012). Unfortunately, in 2015, the shortage of the weighted response rate (51\%) excluded Malaysia from PISA ranking (OECD, 2016). In 2018, placed in Level 2 in PISA reading and a mean score of 415, Malaysia ranked 56 out of 77 countries (OECD, 2019). Level 2 of the eight-levels reading proficiency is the preliminary level in which the learners are capable of identifying the main ideas in a piece of moderate length text, selecting and locating explicit information, reflecting on simple typographical features, and comparing as well as evaluating the rationales supporting their claims (OECD, 2019). In short, Malaysian learners are able to use their background knowledge to draw inferences from the texts. However, they might face problems in handling more complicated texts, thus necessitates the needs to strengthen their reading skills in preparation to be skilled readers.

\section{Reciprocal Teaching as Reading Interventions}

Reciprocal teaching is a well-known technique that is often being used as reading interventions. It is an instructional technique in which small groups of learners collaboratively construct meaning through scaffolded instruction using metacognitive reading strategies (Palincsar, 2017). Parallel with the paradigm shift in reading that regards the success of comprehension depends on readers' ability to integrate their previous knowledge into contextual information, reading comprehension in reciprocal teaching is viewed as equal dialogic interaction between teacher and learners (Smidt, 2015) in which the incorporation of explicit instruction and a combination of reading strategies facilitate the construction of understanding (Oczkus, 2019). Reciprocal teaching helps making the texts more comprehensible by engaging learners actively in the reading process and empowering them to take on the role of the teacher, thus encourages the transition from struggled to independent readers.

Aimed originally at improving reading comprehension for struggling readers, Palincsar and Brown (1984) vouch that the four reading strategies; predicting, questioning, clarifying and summarizing will improve and sustain reading comprehension. Kucan \& Palincsar (2017) refers to prediction as generation of hypothesis or assumptions about the text. Prediction allows the learners to merge their existing knowledge with the new information from the text to anticipate the forthcoming materials (Bailey, 2015; Oczkus, 2019). Prediction is made about the outcome of a future event based upon the pattern of current evidence. Pausing at critical points in reading to draw and test inferences encourages constant refining and verifying of the learners' prediction. 
Text or interpretation confusions unfold another strategy in reciprocal teaching; clarifying. Oczkus (2019) asserts that the process of clarification is an indication of many reasons for comprehension difficulties such as unknown words, unclear phrases, and new concepts. In clarifying, while the text is being read, students are to critically evaluate the meaning of unfamiliar words and phrases and to draw upon the collective knowledge of the team members. This strategy is often used to monitor their own comprehension, critically evaluate whether their reading is making any sense, and then rectify reading problems with suitable reading tools. Furthermore, the discernment of gist, main ideas and themes in the text are of equal importance in this stage. However, clarification of words or phrases should precede the clarification of ideas (Williams, 2010).

If elucidation of unknown vocabulary and concepts happens in clarifying, whereas questioning provides answers that will help to explicate the main ideas of the text. Function as self-check on their understanding of the text, answerable questions can be formulated at varied aspects and levels of the particular reading text (Lenchuk, 2021). Proficient readers ask questions throughout their reading process (Palincsar \& Brown, 1986) because questioning helps to enhance understanding of main ideas of the text they are reading. However, struggling readers often face difficulties in formulating questions due to the complexity of the task. Fortunately, the flexibility of question generating make this an attainable strategy (Palincsar, 2017).

The last strategy, summarizing, is a complex process that requires the merging of multiple skills and strategies, including identifying and recalling main ideas, sequencing, and paraphrasing (Palincasr, 2017). Intended as self-review strategy, summarizing functions as self-assessment for content understanding. Learners' ineptitude to synthesize textual information should not be regarded as failure in performing decontextualization but as an alarming notification that remedial actions such as rereading, are necessary. Hence, modelling as in how to summarise the passage, identify the main idea(s), purpose and intended audience of the text are to be made explicit to the learners. The employment of these four strategies in reciprocal teaching is able to strengthen students' reading comprehension (Gruenbaum, 2012; Palincsar \& Brown, 1984; Yang, 2010). The emergence of new meanings from difficult texts through the application of these reading strategies supports the students' journey of becoming active readers who have overcome their intimidation caused by challenging texts (Gowlerski \& Moon, 2011).

\section{Previous Studies in Reciprocal Teaching}

A review on the literature indicates that reciprocal teaching has gained significant popularity in the teaching of reading comprehension. Palincsar and Brown (1984) attribute the success of reciprocal teaching to the three characteristics; (a) the use of four reading strategies, (b) the explicit instruction and the scaffolding, and (c) the interaction between the learners and the text. These attributes fulfil the key features of effective reading interventions; early interventions (Wanzek et al., 2018), small groups learners of similar reading abilities (Hall and Burns, 2018), and explicit instructional technique modelled and scaffolded by experts (Gilbert, 2018), and extensive opportunities for learners' practice and feedback. Furthermore, the review of the relevant literature agrees with their allegation because generally these studies indicated the potential gains from the combination of these three elements, and the success of knowledge transfer in reading strategies after the interventions. 
The majority of research on reciprocal teaching (Chang \& Lan, 2019; Gilbert, 2018; Kamdideh et al., 2019; Kula \& Budak, 2020; Lenchuk, 2020) resulted in positive outcomes in utilizing reciprocal teaching as reading comprehension interventions. Specifically, the findings indicated that there was an improvement in the learners' ability to resolve comprehension difficulties (Chang \& Lan, 2019; Kamdideh et al., 2019; Kula \& Budak, 2020), a boost in their level of confidence (Kula \& Budak, 2020) as well as an reduction in their level of anxiety when confronting challenging texts (Gilbert, 2018; Kamdideh et al., 2019). In addition, the manifestation of multiple interpretations of a text is made possible through group discussions (Gilbert, 2018). Social interaction in reciprocal teaching also provides opportunities for the learners to share their ideas, to negotiate among their peers (Gilbert, 2018; Kula \& Budak, 2020) and to improve their cognitive and metacognitive reading strategies (Kula \& Budak, 2020). The conduct of previous studies across a wide range of samples also indicated that reciprocal teaching is an effective techniques for learners of varying ages, backgrounds and proficiency levels.

The review highlights few features that make reciprocal teaching an effective reading interventions. Firmly implanted in social constructivism (Vygotsky, 1978), meaning construction in reciprocal teaching are co-constructed through small groups discussion. Palincsar and Brown (1984) claimed that reciprocal teaching rectify comprehension problems by incorporating four reading strategies to help the learners in small groups to interact with the texts. In addition, the element of collaborative learning in reciprocal teaching eliminates comprehension difficulties through sharing of ideas and learners' active involvement in the meaning construction process. This learning condition enables the fostering of learning to happen naturally, thus becoming more successful at delivering effective instruction.

Another prominent element of reciprocal teaching that makes it an effective reading intervention is the scaffolding through explicit instruction from the experts, peer teaching and social interaction. Guidance or modelling by the teacher or expert that precedes the student interaction enables the new construction of ideas or understanding and allows the move across their zone of proximal development. Expert scaffolding is crucial in reciprocal teaching (Palincsar \& Brown, 1984) as it provides proper and sufficient support to assist the achievement of attainable tasks, thus advocating the learning process when dealing with new concepts or ideas. As learners become more competent in applying the new knowledge or skill, these supports are gradually reduced. Nevertheless, substantial assistance can be given when learners encounter challenging texts.

Every attempt in reciprocal teaching is designed for guided reading to occur naturally with the teacher first demonstrates or models the strategy and gradually release their responsibility as facilitator when the learners gain reading proficiency. Therefore, the adoption reciprocal teaching is merely based on the reason it enables the teacher to prepare the learners for a rich comprehension experience when the teacher and learners collaboratively in constructing meaning for the text.

\section{Inquiry-Based Learning}

Inquiry-based learning (IBL) is a form of learning that utilizes questions in the act of seeking information to gain knowledge and skills (Ali \& Ulkar, 2020; Lee, 2014; Wale \& Bishaw, 2020). It is a question-posing method that engages the learners in using problem solving and 
evidence-based reasoning to investigate problems or questions (Ali \& Ulkar, 2020; Wale \& Bishaw, 2020). Bybee (1997) posits that IBL offers learners the opportunity to alter their conceptual understanding through self-reflection and interaction with their peers and environment. This is due to the reason that IBL "enables critical thinking, flexible problem solving, and the transfer of skills and use of knowledge in new situations" (Darling-Hammond, 2008, p.2).

In classroom learning, as elucidated by Dane, Thomas and Boynton (2011), IBL engages learners in powerful investigation-based learning because it allows them to take ownership of their learning as they form their own questions, gather data, analyse their findings and share their result. In such learning environment, the teacher is not a provider of knowledge but acts as a facilitator to scaffold the learning process (Wale \& Bishaw, 2020). Specifically in language classrooms, besides significantly enhancing linguistics competence (Lee, 2014), IBL ensures the authenticity of language learning situations that requires the learners to use their content knowledge in bridging between the classroom learning and own experience in real world situations (Shih, Chuang \& Hwang, 2010). Good questioning method in inquiry-based learning results in more engaging learning experience, thus leads to development of cognitive and metacognitive capabilities that facilitate the emergence of more creative, reflective and self-directed learners (Wale \& Bishaw, 2020). An explicit focus in IBL ensures deeper language and content acquisition than traditional direct instruction (Aditomo \& Klieme, 2020; Wale \& Bishaw, 2020).

However, Stripling (2003) highlights a distinct difference between inquiry-based learning and problem-solving. In problem-solving model, the learning process is usually controlled with minimal cognitive processes as learners only look for answers to the problem introduced by the teacher. In contrast, the inquiry-based learning model allows learners to research, evaluate and test new information by making predictions and forming hypotheses before comparing it with their previous understanding and drawing conclusions from it. The application and sharing of the new understanding result in the gain of new perspectives and its relation to the world around them. Moore and Moore (1984) summarised the difference between inquiry-based learning and problem-solving by professing that even though inquirybased learning concerns problem solving, it focuses solely on the process of investigating the problem, rather than reaching a correct solution to that problem.

A noteworthy inquiry-based learning cycle approach is the Biological Sciences Curriculum Study (BSCS) $5 E$ Instructional model (Bybee et al., 2006) which comprises five learning cycle stages; Engagement, Exploration, Explanation, Elaboration, and Evaluation (refer to Figure 1). Deeply rooted in cognitive psychology, constructivist-learning theory, directive inquiry and best practices in science teaching, this model has been gradually adopted into second language teaching (Herman et al., 2018; McElvain \& Smith, 2016; Moses et al., 2015; van de Graaf et al., 2020; Wale \& Bishaw, 2020). The cycle starts with engagement phase that promotes prior assessment of learners' knowledge and mental focus on the concept before progressing to the exploration phase that provides concrete, hands-on experiences where learners express their current conceptions and clarify puzzling elements of the prior phase. The third phase, explanation is a phase that enables learners to describe their understanding, pose questions and critically reflect on the concepts they have been exploring. This phase ends with the teacher stepping in to clarify misconceptions. The fourth phase, elaboration, 
aims at encouraging learners to apply and check their new understanding with their peers before moving into the final phase, evaluation, where teacher makes observations and looks for evidence in their learning. Although this model is proposed in serial order, its flexibility and dynamic background (Bybee, 1997) make it possible to reverse the cycle whenever necessary.

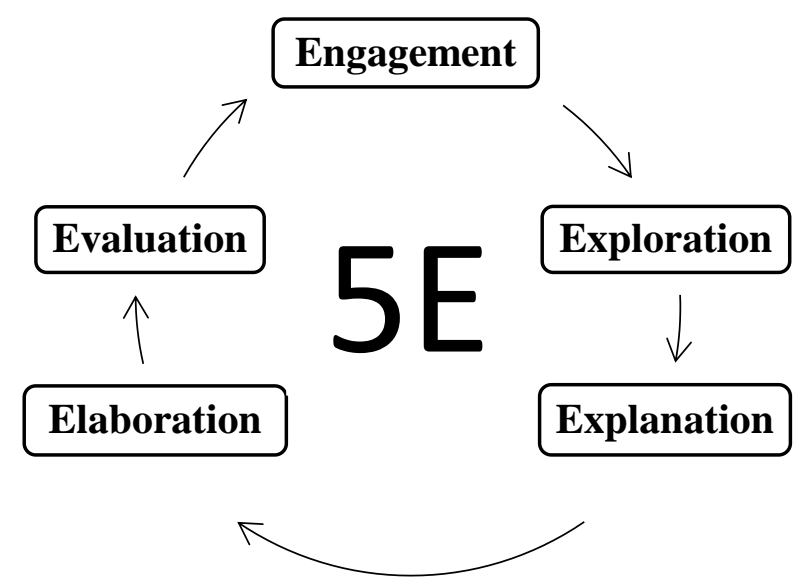

Figure 1: BSCS 5E Model (Bybee et al., 2006)

Although this prominent model has solid base of research and is grounded in educational theory and to support its effectiveness in the teaching of science, the concept is equally wellsuited in ESL setting (Lee, 2014). The application of strategies and techniques of IBL engage learners in meaningful discussions, thus resulted not only in active and sustainable learning outcomes, but also improves learners' critical thinking skills (Wale \& Bishaw, 2020). The question and answer sessions throughout the learning process ensure the tracking of the progress and learning outcomes (Lee, 2014). Therefore, this model ensures the organization of systematic application of effective reading strategies development in reading comprehension classrooms thus necessitates a dire need to adopt this model into the framework.

\section{Previous Studies in Inquiry-Based Learning}

A critical review on the literature supports the allegation made by Lee (2014) regarding the exiguity of the usage of the inquiry technique in ESL classrooms. The scarcity of its transfer and application into ESL classroom is conspicuously glaring. For the past few years, research on the application of IBL into ESL teaching and learning were mostly conducted overseas such as those by Moses et al. (2015) in the United States of America, McElvain and Smith (2016) in Northern California, Herman et al. (2018) in Indonesia, van de Graaf et al., (2020) in Netherlands and Wale and Bishaw (2020) in Africa.

Scrutinizing the details of these past studies reveals that although the $5 \mathrm{E}$ Instructional Model originates from Biological Sciences, the adoption of this model into second language based research (Herman et al., 2018; McElvain \& Smith, 2016; Moses at el., 2015; Wale \& Bishaw, 2020 ) is possible. The studies resulted in positive effects in cognitive and verbal development of bilingual children such as how to activate background knowledge, comprehension monitoring, predicting outcomes and planning ahead (McElvain \& Smith, 2016). It also 
indicates that in inquiry-based settings, content knowledge, critical thinking, language development and creativity flourish (Moses at el., 2015; Wale \& Bishaw, 2020). Furthermore, the study by Herman et al., 2018 also resulted in positive outcomes in developing reading proficiency, engaging learners with challenging texts, activating background knowledge, as well as enhancing teamworks and learning process.

Clearly, the literature highlights the importance of inquiry-based instruction in ESL classrooms. Such supposition is widely deemed as the philosophical foundation for adopting inquiry-based learning is necessary in tackling the needs of current ESL learners. As inquiries allow the development of creating knowledge, thus is perfectly in conformity with the modern discourse in preparing students for the new globalization era. IBL therefore has become the most appealing advocacy in education, thus rationalize the adoption of this instruction into this framework.

The adoption of this model sequences the process and strategies of reciprocal teaching more systematically, thus minimizing the progress obstruction in reading comprehension. The incorporation of IBL into this study is to support reciprocal teaching because both concepts share the same nature; interactive instructional approach. An effective inquiry technique allows meaning construction through self-discovery, ignition of cognitive and metacognitive skills and independent learning. Although originated from science background, the concept and mechanism are equally well-suited to ESL classrooms as the formulation of questions will result in prediction and hypotheses formation to evaluate the new information. As students negotiate the meanings with their background knowledge, application of new understandings to the new contexts is shared with peers.

\section{ADDIE}

Abbreviated for Analysis, Design, Development, Implementation and Evaluation, the ADDIE framework (refer to Figure 2) is a cyclical instructional system design that offers a systematic step by step guidelines to establish, test and validate new products, procedures, or techniques (Molenda, 2003). An methodical completion of each stage focusing on rumination and reiteration is a prerequisite of this framework. The sequential outcomes and feedback from the formative evaluation of each stage ensure continuous improvement in the instructional design.

The first stage, Analysis, is the core of all other stages in this ADDIE. In this stage, an audit of the current situations that focuses on the identification of the problems and determination of possible solutions will be performed. As the outputs of this stage often include the instructional goals and intended tasks, they function as inputs for the next stage, Design, which aims at determining the learning goals, designing contents that adhere to the curriculum, formulating assessments, and producing storyboards or prototypes. 
The third stage, Development involves the construction and production of lesson plans and materials which will be put into action in the following stage. The fourth stage, Implementation is the stage that promotes learners' understanding and mastery of the learning objectives and materials in the actual situations whereas the final stage, Evaluation, measures the effectiveness of the instruction. However, Molenda (2003) advocates for the use of both formative and summative evaluation throughout the entire process. Formative evaluation functions as a means to constantly improve the current instruction before the final

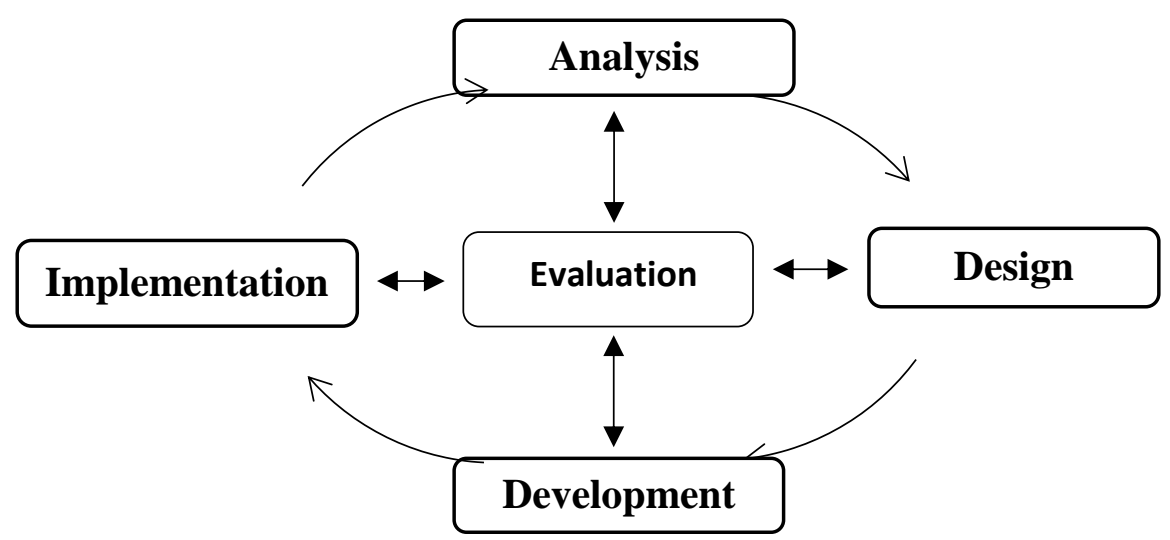

version is implemented whereas summative evaluation aims at assessing the overall effectiveness of the instruction.

Figure 2: The ADDIE framework

\section{Conceptual Framework}

Based on the review of reading comprehension in Malaysian ESL settings, concepts and theories of reciprocal teaching and inquiry-based learning, this conceptual framework aims at conceptualizing reciprocal teaching strategies in inquiry-based reading comprehension classrooms for ESL learners through the development of a reading comprehension module consisting of collaborative and inquiry-based activities.

Figure 3 represents the integration of the four strategies in reading strategies into an inquirybased reading comprehension classrooms that operationalised the $5 \mathrm{E}$ model general concepts of the conceptual framework. ADDIE framework is adopted to guide the process of the module development due to its ability in providing constant feedback for continuous improvement in a systematic, detailed and focused approach. The cycle began with an audit of the learners' current knowledge in reading strategies and their goals in reading through needs analysis. The process of identification and development of learning objectives and activities that target at the attainment of reading goals was fully based on the feedback gathered from the Analysis stage, thus resulted in the decision to weave Palincsar and Brown's (1984) reciprocal teaching into Bybee et al.'s (2006) BSCS 5E Instructional Model for the purpose of as comprehension-fostering and comprehension-monitoring activities in the module in the design and development stage of ADDIE. After series of module validation, the module was ready for actual implementation. The final stage includes the collection of data on students' performance in terms of reading achievement and conceptual change as feedback to identify areas that requires improvement. 


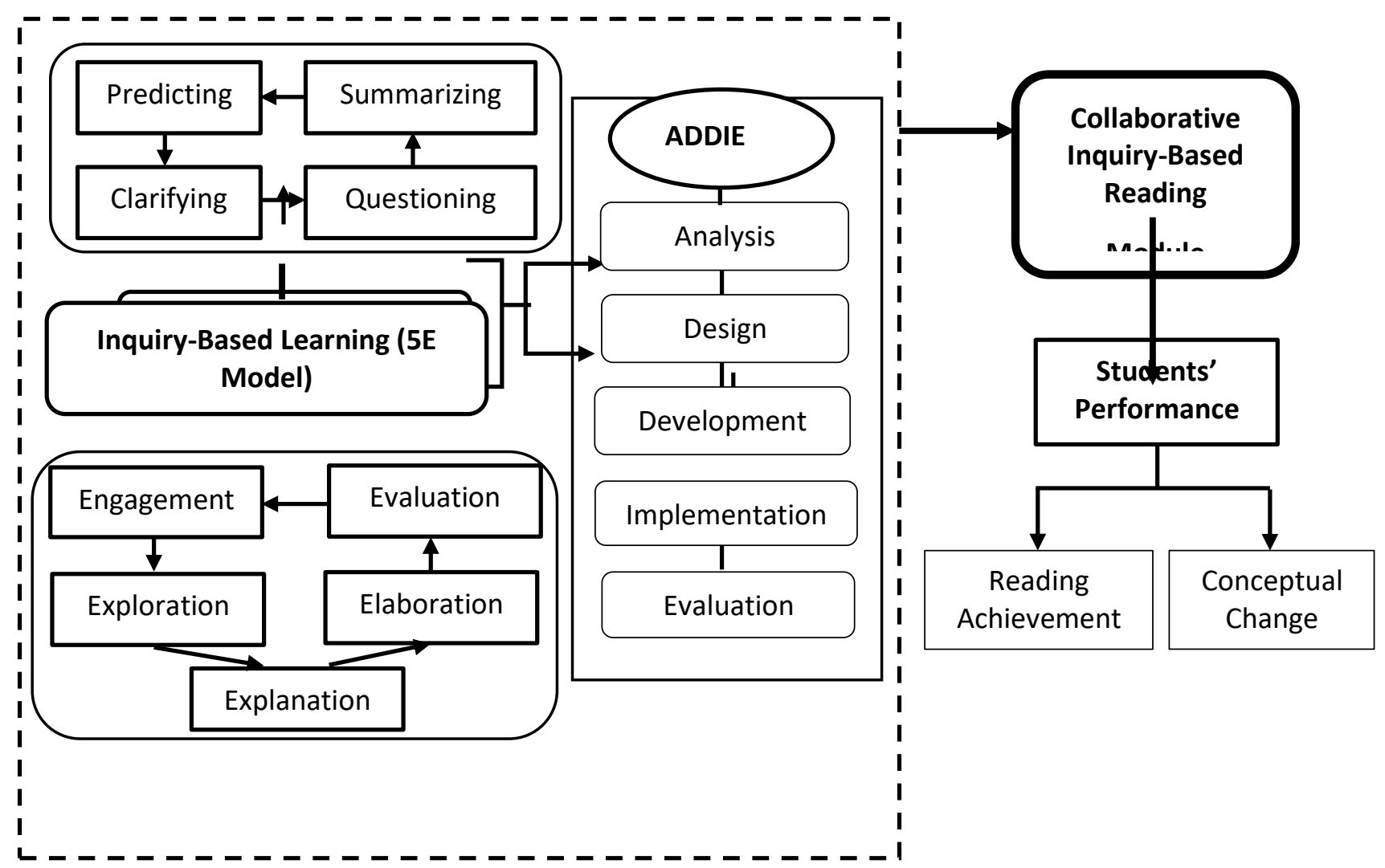

Figure 3: The Collaborative Inquiry-Based Reading Module framework

\section{Conclusion}

In bridging the comprehension gap, awareness on cognitive and metacognitive reading strategies (Dardjito, 2019; Mokhtari et al., 2018; Teng, 2019), modelling of the reading purposes and strategies (Brevik, 2019), and the exertion of authentic reading materials with local settings (Kanoksilapatham \& Suranakkharin, 2018) are crucial elements that help to escalate readers' reading comprehension. In spite of decades of research on learners' difficulties in reading comprehension, only a few examples of modules have addressed the issues related to the identification of the compelling elements inherent in multiple reading strategies and little is known about the issue of how these strategies can be combined in comprehension instruction. Consequently, necessitates the need to suggest a reading comprehension module incorporating explicit instruction of reading comprehension strategies, modelling of meaningful localised transactions during the reading process and theorizing both cognitive and metacognitive strategies in the process of meaning construction through the implementation of collaboration and inquiry-based learning strategies in reading comprehension, hence resulted in the development of the Collaborative Inquiry Reading Module which is intended to be integrated into reading comprehension classrooms as a way for the teachers to teach reading comprehension more effectively.

\section{References}

Aditomo, A., \& Klieme, E. (2020). Forms of inquiry-based science instruction and their relations with learning outcomes: evidence from high and low-performing education systems. International Journal of Science Education, 42, 1-22. https://doi.org/10.1080/09500693.2020.1716093. 
Ali, H., \& Ulkar, V. (2020). The effect of inquiry-based approach on development of reading and writing kkills of a university EFL students. Asian EFL Journal, 27, 84-100.

Bailey, E. (2015). Reading comprehension skills: Making predictions. Retrieved Dec 12, 2019, from http://specialed.about.com/od/readingliteracy/a/Reading-Comprehension-SkillsMaking-Predictions.htm

Brevik, L. M. (2019). Explicit reading strategy instruction or daily use of strategies? Studying the teaching of reading comprehension through naturalistic classroom observation in English L2. Read Writ, 32, 2281-2310. https://doi.org/10.1007/s11145-019-09951-w

Bybee, R. (1997). Achieving scientific literacy. Portsmouth, NH: Heinemann.

Bybee, R. W., Taylor, J.A., Gardner, A., Van Scatter, P., Powell, J. C., Westbrook, A., \& Landes, N. (2006). BSCS SE instructional model: Origins and effectiveness. A report prepared for the Office of Science Education, National Institutes of Health. Colorado Springs, CO: BSCS.

Chang, M. M., \& Lan, S. W. (2019). Exploring undergraduate efl students' perceptions and experiences of a moodle-based reciprocal teaching application. The Journal of Open, Distance and e-Learning. doi: 10.1080/02680513.2019.1708298

Dardjito, H. (2019). Students' metacognitive reading awareness and academic english reading comprehension in EFL context. International Journal of Instruction, 12(4), 611-624. https://doi.org/10.29333/iji.2019.12439a

Dana, N. F., Thomas, C., \& Boynton, S. (2011). Inquiry: A districtwide approach to staff and student learning. Thousand Oaks, California: Corwin.

Darling-Hammond, L. (2008). Introduction: Teaching and learning for understanding. powerful learning: What we know about teaching for understanding (pp. 19). San Francisco, CA: Jossey-Bass.

Elleman, A. M, \& Oslund, E. L. (2019). Reading comprehension research: Implications for practice and policy. Policy Insights from the Behavioural and Brain Sciences, 6(1), 3-11. https://doi.org/10.1177/2372732218816339

Gilbert, F. (2018). Riding the reciprocal teaching bus. A teacher's reflections on nurturing collaborative learning in a school culture obsessed by results. Changing English, 25(2), 146-162. doi:10.1080/1358684x.2018.1452606

Grabe, W., \& Stoller, F.L. (2020). Teaching and researching reading ( $3^{\text {rd }}$ Ed). New York: Routledge.

Gorlewski, J., \& Moon, S. (2011). Research for the classroom: Trying on reciprocal teaching: A novice's struggle becomes a veteran's success. The English Journal, 101(2), 97-100.

Gruenbaum, E. A. (2012). Common literacy struggles with college students: Using the reciprocal teaching technique. Journal of College Reading and Learning, 42(2), 109- 116.

Hall, M., \& Burns, M. (2017). Meta-analysis of targeted small-group reading interventions. Journal of School Psychology, 66. https://doi.org/10.1016/j.jsp.2017.11.002.

Herman, E., Yunus, N., \& Pammu, A. (2018). The role of inquiry-based learning to improve reading comprehension of EFL students. ELS Journals on Interdisciplinary Studies on Humanities, 1(1), 13-20.

Kamdideh, Z., Vaseghi, R., \& Talatifard, S. (2019). The effects of 'reciprocal teaching of reading' and 'cooperative integrated reading and composition' on the reading comprehension of Iranian EFL intermediate students. Theory and Practice in Language Studies, 9, 11111117. 
Kanoksilapatham, B. \& Todsapon, Suranakkharin. (2018). Celebrating local, going global: Use of northern thainess-based english lessons. Journal of Asia TEFL, 15, 292-309. 10.18823/asiatefl.2018.15.2.1.292.

Kim, YS., Lee, H., \& Zuilkowski, S. (2020). Impact of literacy interventions on reading skills in low- and middle-income countries: A meta-analysis. Child Development. 91. 638-660. 10.1111/cdev.13204.

Kucan, L., \& Palincsar, A. (2017). Text analysis: Critical component of planning for text-based discussion focused on comprehension of informational texts. Literacy Research and Instruction. 1-17. 10.1080/19388071.2017.1400612.

Kula, S. S., \& Budak, Y. (2020). The effects of reciprocal teaching on reading comprehension, retention on learning and self-efficacy perception. Pegem Eğitim ve Öğretim Dergisi, 10(2), 493-522. http://dx.doi.org/10.14527/pegegog.2020.017

Lian, Y. K., \& Azlina Abdul Aziz. (2020). An action research on metacognitive reading strategies instruction to improve reading comprehension. International Journal of English Language and Literature Studies, Asian Economic and Social Society, 9(2), 86-94.

Lee, Y. H. (2014). Inquiry-based teaching in second and foreign language pedagogy. Journal of Language Teaching and Research, 5(6), 1236-1244.

Lenchuk, I. (2021). Reciprocal Teaching as an Instructional Strategy for Identifying Reading Literacy Problems: A Case Study of an Omani EFL Classroom. International Journal of English Language and Literature Studies, 10(1), 1-10.

MacKay, E. J., Larcohe, A., Parrila, R., \& Deacon, S. H. (2019). A beginning exploration of text generation abilities in university students with a history of reading difficulties. Dyslexia. https://doi.org/10.1002/dys.1610.

Malaysia of Education Malaysia. (2018). Malaysia Education Blueprint 2013-2025: Annual Report 2017. Malaysian Ministry of Education. Putrajaya.

McElvain, C. M., \& Smith, H. A. (2016). Curiosité: Inquiry-based instruction and bilingual learning. Journal of Curriculum and Teaching, 5(2), 63-75.

Mokhtari, K., Dimitrov, D., \& Reichard, C. (2018). Revising the metacognitive awareness of reading strategies inventory (MARSI) and testing for factorial invariance. Studies in Second Language Learning and Teaching, 8, 219-246. 10.14746/ssllt.2018.8.2.3.

Molenda, M. (2003). In search of the elusive ADDIE model. Performance Improvement, 42(5), 34-36.

Moore, G. E., \& Moore, B. A. (1984). The problem solving approach to teaching: Has it outlived its usefulness? The Journal of the American Association of Teacher Educators in Agriculture, 25(2), 3-10.

Moses, L., Busetti-Fervert, R., \& Pritchard, R. (2015). Inquiry as ESL: Support emerging bilinguals and content and language development. The Reading Teacher, 68(6), 435447.

Oczkus, L. D. (2019). Reciprocal teaching at work ( $3^{\text {rd }}$ ed.). International Literacy Association.

OECD (2010), PISA 2009 Results: Executive summary. PISA, OECD Publishing, Paris.

OECD (2012), PISA 2012 Results in focus: What 15-year-olds know and what they can do with what they know. PISA, OECD Publishing, Paris.

OECD (2016), PISA 2015 results (Volume I): Excellence and equity in education. PISA, OECD Publishing, Paris.

OECD (2019), PISA 2018 Results (Volume I): What Students Know and Can Do, PISA, OECD Publishing, Paris, https://doi.org/10.1787/5f07c754-en 
Oktavia, D., \& Fitriana, D. (2017). Developing students' reading comprehension skills through reciprocal teaching strategy. Advances in Social Sciences Education and Humanities Research, 82, 23-27.

Palincsar, A. S., \& Brown, A. L. (1984). Reciprocal teaching of comprehension-fostering and comprehension monitoring activities. Cognition and Instruction, 1(2), 117-175.

Palincsar, A. S., \& Brown, A. L. (1986). Interactive teaching to promote independent learning from text. Reading Teacher, 39(8), 771-777

Shih, J. L., Chuang, C. W., \& Hwang, G. J. (2010). An inquiry-based mobile learning approach to enhancing social science learning effectiveness. Educational Technology \& Society, 13(4), 50-62. http://www.ifets.info/journals/13_4/6.pdf

Smidt, S. (2015). An abc of early childhood education: A guide to some of the key issues. London: Routledge.

Stripling, B. K. (2003). Inquiry-based learning. In B.K. Stripling \& S. Huges-Hassell (Eds.), Curriculum Connections through the Library, 3-39. Westport, CT: Libraries Unlimited.

Teng, M. F. (2019). The benefits of metacognitive reading strategy awareness instruction for young learners of English as a second language. Literacy.

Ulu, H. (2019). Examining the relationships between the attitudes towards reading and reading habits, metacognitive awarenesses of reading strategies, and critical thinking tendencies of pre-service teachers. International Journal of Contemporary Educational Research, 6(1), 169-182. https://doi.org/10.33200/ijcer.549319

UNESCO. (2017b). More than one-half of children and adolescents are not learning worldwide. Fact Sheet No. 46, UIS/ FS/2017/ED/46. Montreal, QC: UNESCO Institute for Statistics. Retrieved from http://uis.unesco.org/sites/ default/files/documents/fs46-more-thanhalf-childrennot-learning-en-2017.pdf

van der Graaf, J., Segers, E., \& de Jong, T. (2020). Fostering integration of informational texts and virtual labs during inquiry-based learning. Contemporary Educational Psychology, 62.

Vygotsky, L. S. (1978). Mind in Society: The Development of Higher Psychological Processes. Cambridge, MA: Harvard University Press.

Wale, B., \& Bishaw, K. (2020). Effects of using inquiry-based learning on EFL students' critical thinking skills. Asian-Pacific Journal of Second and Foreign Language Education, 5. https://doi.org/10.1186/s40862-020-00090-2.

Wanzek, J., Stevens, E. A., Williams, K., Scammacca, L. N., Vaughn, S., \& Sargent, K. (2018). Current Evidence on the Effects of Intensive Early Reading Interventions. Journal of Learning Disabilities, 51.002221941877511. https://doi.org/10.1177/0022219418775110.

Williams, J. A. (2010). Taking on the role of questioner: Revisiting reciprocal teaching. The Reading Teacher, 64(4), pp. 278-281.

Yang, Y. F. (2010). Developing a reciprocal teaching/learning system for college remedial reading instruction. Computers \& Education, 55(3), 1193-1201. 